\title{
COMPACTION AND CONSOLIDATION CHARACTERISTICS OF LATERITIC SOIL OF A SELECTED SITE IN IKOLE EKITI, SOUTHWEST NIGERIA
}

\author{
A. Bolarinwa ${ }^{1,}{ }^{*}$, J. B. Adeyeri ${ }^{2}$ and T. C. Okeke ${ }^{3}$ \\ 1,2,3 Department of Civil EngineERIng, Federal University Oye Ekiti, Ekiti State, NIGERIA. \\ E-mail addresses: ${ }^{1}$ ademola.bolarinwa@fuoye.edu.ng, 2 joseph.adeyeri@fuoye.edu.ng, \\ 3 tochukwu.okeke@fuoye.edu.ng
}

\begin{abstract}
The compaction and consolidation characteristics of lateritic soils in Ikole area of Ekiti State were investigated. The investigation was carried out through laboratory tests on disturbed and undisturbed soil samples obtained from three borings (BH1, BH2, and BH3) of Holy Apostolic Nursery/Primary School, Ootunja, Ikole Local Government Area (L.G.A.) of Ekiti State Southwest, Nigeria. The soils are all lateritic and mostly fine-grained. Compaction tests indicate maximum dry densities of $2.05 \mathrm{Mgm}^{-3}, 1.78 \mathrm{Mgm}^{-3}$, and $1.69 \mathrm{Mgm}^{-3}$ at optimum moisture contents of $14.3 \%, 20.7 \%$ and $19.6 \%$ for soil samples obtained from BH1, BH2 and BH3 respectively. Compression indices $\left(C_{c}\right)$ obtained from oedometer tests are $0.04816,0.03820$ and 0.04318 while the calculated coefficients of volume compressibility $\left(m_{v}\right)$, are $1.308^{*} 10^{4}, 1.065 * 10$ ${ }^{4}$ and $1.093^{*} 10^{-4} \mathrm{~m}^{2} \mathrm{kN}^{-1}$ for samples in BH1, BH2 and BH3 respectively. The unsoaked California Bearing Ratio (CBR) value at $2.5 \mathrm{~mm}$ penetration ranges from $42.10 \%$ to $92.40 \%$ and $C B R$ value at $5.0 \mathrm{~mm}$ penetration ranges from 52.70 to 89.10\% indicative of good materials for road subgrade, sub-base and base courses.
\end{abstract}

Keywords: Compaction, Consolidation, CBR, Southwest Nigeria.

\section{INTRODUCTION}

The terms "Compaction" and "Consolidation" are often interchangeably used. Compaction is the process of increasing the density of a soil by packing the particles closer together with a reduction in the volume of air: there is no significant change in the volume of water in the soil, while on the other hand, consolidation is the gradual reduction in volume of a fully saturated soil of low permeability due to drainage of some of the pore water, the process is continued until the excess pore water pressure set up by increase in total stress has completely dissipated; the simplest case is that of onedimensional consolidation in which a condition of zero lateral strain is implicit, [1]. Compaction is an artificial process, which basically involves densification of the soil mass through reduction of air in voids of the soil mass while the later is a natural process of gradual reduction in volume of the soil mass (settlement) through expulsion of the excess pore water in the soil over a period of time. It should also be noted that compaction is not time dependent while time is a major factor for completion in consolidation process. In most times, not all in-situ soil geotechnical properties are directly suitable for civil engineering works. Since borrowing is now considered uneconomical in recent times, many researchers for example [2 - 7] have attempted to utilize various locally available materials for stabilization/ improvement of some geotechnical properties of in-situ soil around Ekiti State and other Southwest States in Nigeria. Most of these materials includes wastes from agricultural products and examples include; rice husk, sugar cane straw, coconut shell, fly ash, palm kernel shell ash (PKSA), saw dust ash (SDA), forage ash, groundnut shell ash, hardwood and softwood ashes to mention but a few. These materials were found to improve soil geotechnical properties such as Liquid Limit (LL), Plastic Limit (PL), Plasticity Index (PI), Maximum Dry Densities (MDD), Optimum Moisture Content (OMC), Soaked \& Unsoaked California Bearing Ratio (CBR).

However, no previous attempt has been made to investigate soil compaction and consolidation properties around Ikole Ekiti Area of Ekiti State, Nigeria. Therefore, it is the aim of this research to evaluate the compaction and consolidation characteristics of soils in this area. This work also established the economic values of lateritic soils found in the study area and their engineering implications discussed. Objectives of this research include, establishment of the stratigraphic soil profile, determining the water table level, and investigating the mechanical soil properties since, the literature above has not recorded any history of such probe in the study area. Information on strength 
characteristics of soils in the study area has been published in [8]. The results obtained in this work will consolidate the data requirement for a web-based geotechnical database management system for Nigerian soils as proposed by [9].

\section{MATERIALS AND METHODS}

\subsection{Study Area and Geology}

The study area is situated at Holy Apostolic Nursery/Primary School, Ootunja, Ikole Local Government Area (L.G.A.) of Ekiti State Southwestern Nigeria and it is accessible through Oye-Ilupeju-ItapaOsi-Ikole and Ado-Ijan-Iluomoba-Ijesha Isu-Ikole route. Ootunja is one of the twenty four towns and villages constituting Ikole L.G.A., [10]. Ikole is located at $7.783333^{\circ} \mathrm{N} ; 5.516667^{\circ} \mathrm{E}$. The general geology of Ekiti State is well researched for example, [11 - 16]. The geology of the area is underlain by the Precambrian rocks of the Basement Complex of Southwestern Nigeria which covers about $50 \%$ of the land surface in Nigeria. The general geological map of Ekiti State is shown in Figure 1. The major lithological units include the granite gneiss, migmatites gneiss and charnockite, [17]. The Basement rocks show great variations in grain size and in mineral composition. The rocks are quartz gneisses and schists consisting essentially of quartz with small amounts of white micaceous minerals. In grain size and structures, the rocks vary from very coarse grained pegmatite to medium grained gneisses. The site layout showing all boring points and features is shown in Figure 2. The position of the borings is as shown in Table 1.

Table 1: Bore Hole Coordinates and depth explored (m)

\begin{tabular}{lll}
\hline $\begin{array}{l}\text { Borehole } \\
\text { No. }\end{array}$ & $\begin{array}{l}\text { Coordinates (Northings \& } \\
\text { Eastings) }\end{array}$ & $\begin{array}{l}\text { Bored Depth } \\
(\mathrm{m})\end{array}$ \\
\hline BH01 & $0862222 \mathrm{mN} ; 0774975 \mathrm{mE}$ & 19.5 \\
BH02 & $0862245 \mathrm{mN} ; 0774967 \mathrm{mE}$ & 19.5 \\
BH03 & $0862174 \mathrm{mN} ; 0775010 \mathrm{mE}$ & 19.5 \\
\hline
\end{tabular}

\subsection{Field Work}

Basically, the scope of field work involves; exploration of three (3) geotechnical boreholes to refusal depth (rock layer) by using the shell and auger boring technique. A mobile Dando 150 mobile rig complete with Standard Penetration Tests (SPT) accessories was mobilized for the exercise. Although, sampling procedure is dictated by the nature and thickness of subsoil encountered in the course of the investigation, a summary of sampling and field testing procedure followed in the course of drilling was given as:

(i) Ordinary disturbed samples were collected within the first $1 \mathrm{~m}$ of drilling and at change of strata. Samples from the cutting shoe in the case of undisturbed sampling and from the split spoon barrel in respect of SPT were also collected as disturbed samples and placed in sealed polythene nylons.

(ii) Undisturbed samples were collected at relevant intervals in cohesive soils. This sampling is designated with a 'U' on borehole logs.

(iii) In some cases, taking of undisturbed samples was attempted but futile as some of the clays were too sandy to stay in the $100 \mathrm{~mm}$ diameter sampling tubes.

(iv) Standard Penetration Tests (SPT) were carried out at $1.5 \mathrm{~m}$ depth intervals particularly in cohesionless materials on the site. This test involves obtaining the number of blows [N-values] producing the last $300 \mathrm{~mm}$ of penetration of $50 \mathrm{~mm}$ Split Spoon sampler in connection with an overall $450 \mathrm{~mm}$ penetration test by $63.4 \mathrm{~kg}$ hammer free falling through $760 \mathrm{~mm}$.

(v) Samples were numbered based on bore-hole number and subsequent sample numbers, such as bore hole 1, sample 1 abbreviated as BH1-S1, etc.

Site investigation programme was carried out in agreement with the procedure set out in British Standards, [18]. All the tests were also carried out in the Geotechnical Engineering laboratory of Trevi Foundations Nigeria Ltd., Lagos, Nigeria.

\subsection{Laboratory Testing:}

Following the procedure spelt out in [18] - Testing Soils for Civil Engineering Purposes, Laboratory tests were carried out as follows:

(a) To determine Physical Properties of Soil \{Classification\}: (i) Moisture content determination; (ii) Consistency limit tests [Atterberg]; (iii) Particle size analysis

(b) To determine Mechanical Properties of Soils: The following tests were undertaken: Compaction, Oedometer and CBR tests.

\section{RESULTS AND DISCUSSION}

The results of classification tests (grain size analysis, natural moisture content, Atterberg's limits and soil classification) as well as the compaction, Oedometer and CBR tests are discussed below;

\subsection{Particle Size Analysis}

The percentage range of soils passing through No. 200BS sieve ranges between 15.4 to $74.2 \%$. The particle size distribution curve of some selected soil samples is shown in Figure 3. According to [19], most of the soil samples can be recommended as suitable for sub-grade, sub-base and base course materials as the percentage by weight finer than No.200BS test sieve is less than 35\%. 


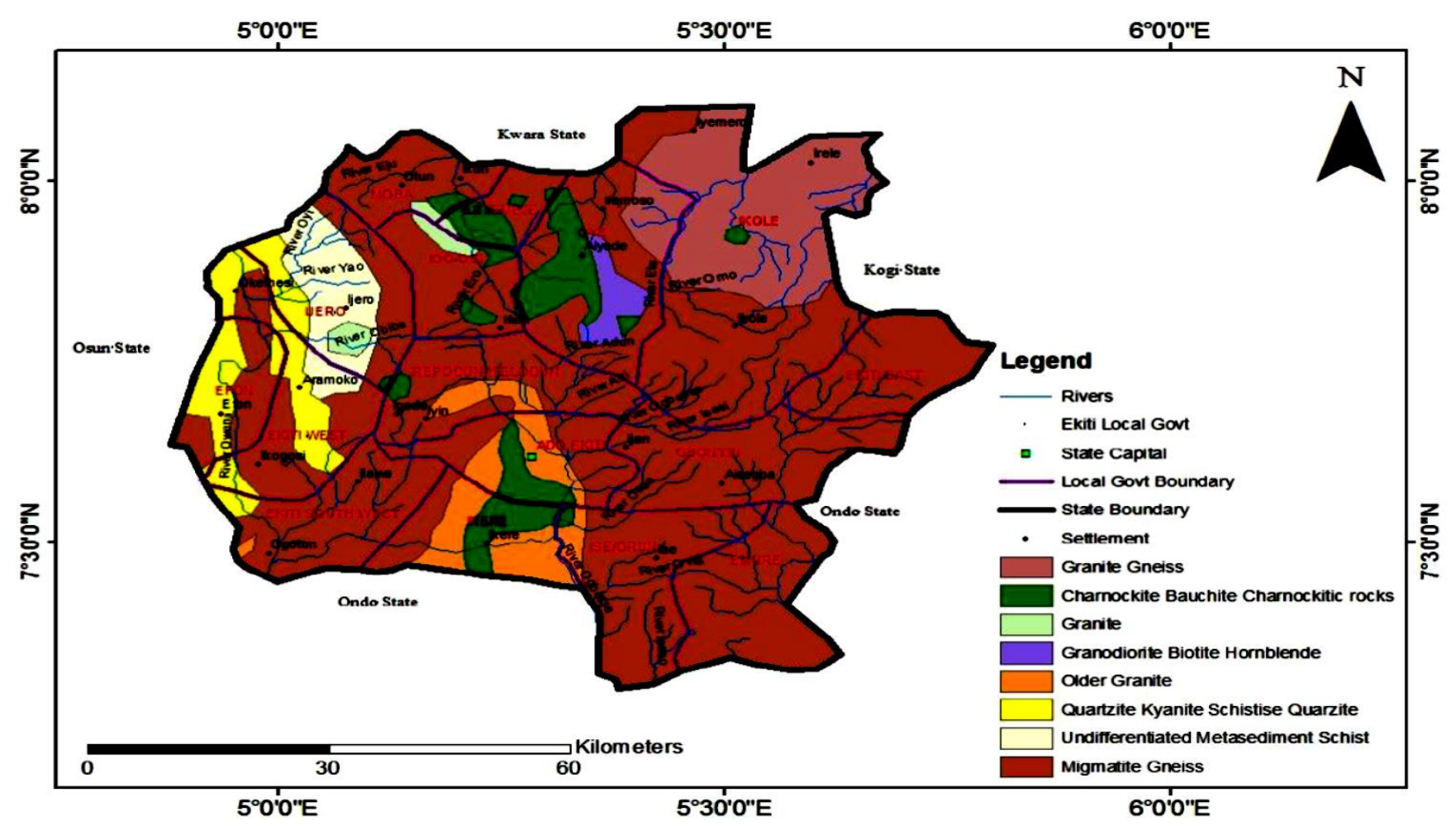

Figure 1: The Geological Map of Ekiti State, adapted after [2]

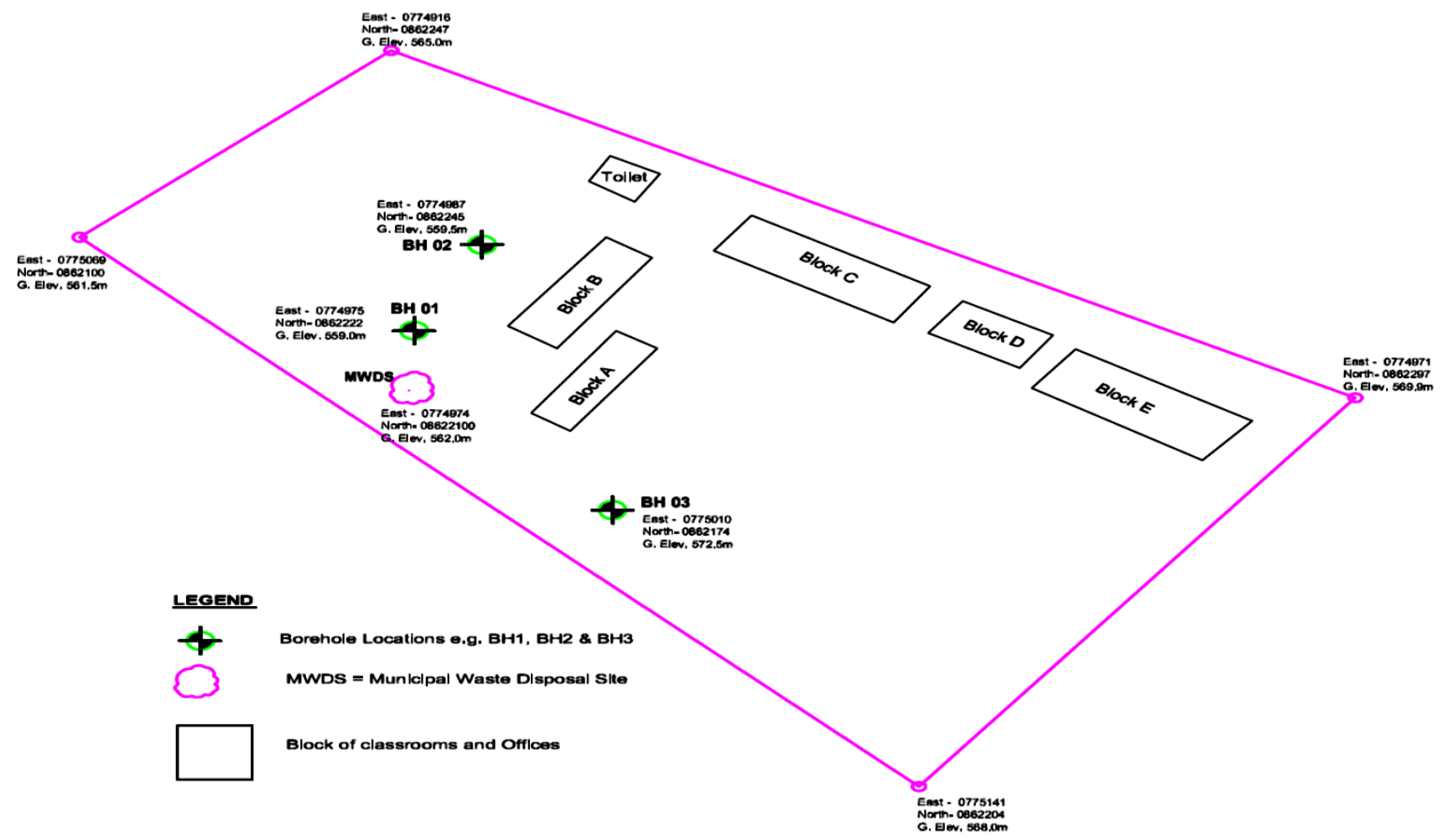

Figure 2: Site Layout of the Study Area Showing Test Locations

The percentage range of the grain sizes are specified as follows: gravel; $0.00-20.72 \%$, coarse grained sand; 0.00 - 7.19\%, medium grained sand; 5.53 - 33.53\%, fine grained sand; $7.02-45.51 \%$ and fines; $30.7-74.25 \%$. The above values indicate that most of the soils are fines (clay). Classifications based on the unified soil classification systems (USCS) on the numerous soil samples indicate four distinct groups namely; $\mathrm{CL}, \mathrm{CL} / \mathrm{ML}$, SM/ML and CL/ML. Table 2 shows some observed physical properties of soil samples. 
Table 2: Physical Properties of Soil Samples

\begin{tabular}{lccc}
\hline Physical Property & BH1 & BH2 & BH3 \\
\hline Specific Gravity & $2.70-2.80$ & $2.75-2.86$ & $2.78-2.88$ \\
Natural Moisture Content (\%) & $13-20$ & $13-18$ & $14-20$ \\
Permeability (cm/s) & $1.12^{*} 10^{-4}$ & $1.35^{*} 10^{-4}$ & $2.06^{*} 10^{-4}$ \\
Liquid Limit (\%) & $48-54$ & $44-58$ & $53-58$ \\
Plastic Limit & $18-20$ & $24-30$ & $24-26$ \\
Plasticity Index (\%) & $30-34$ & $26-31$ & $29-34$ \\
USCS Classification & CL or CL/ML or SM/ML & CL/ML or SM/ML & CL or CL/ML or SM/ML \\
\hline
\end{tabular}

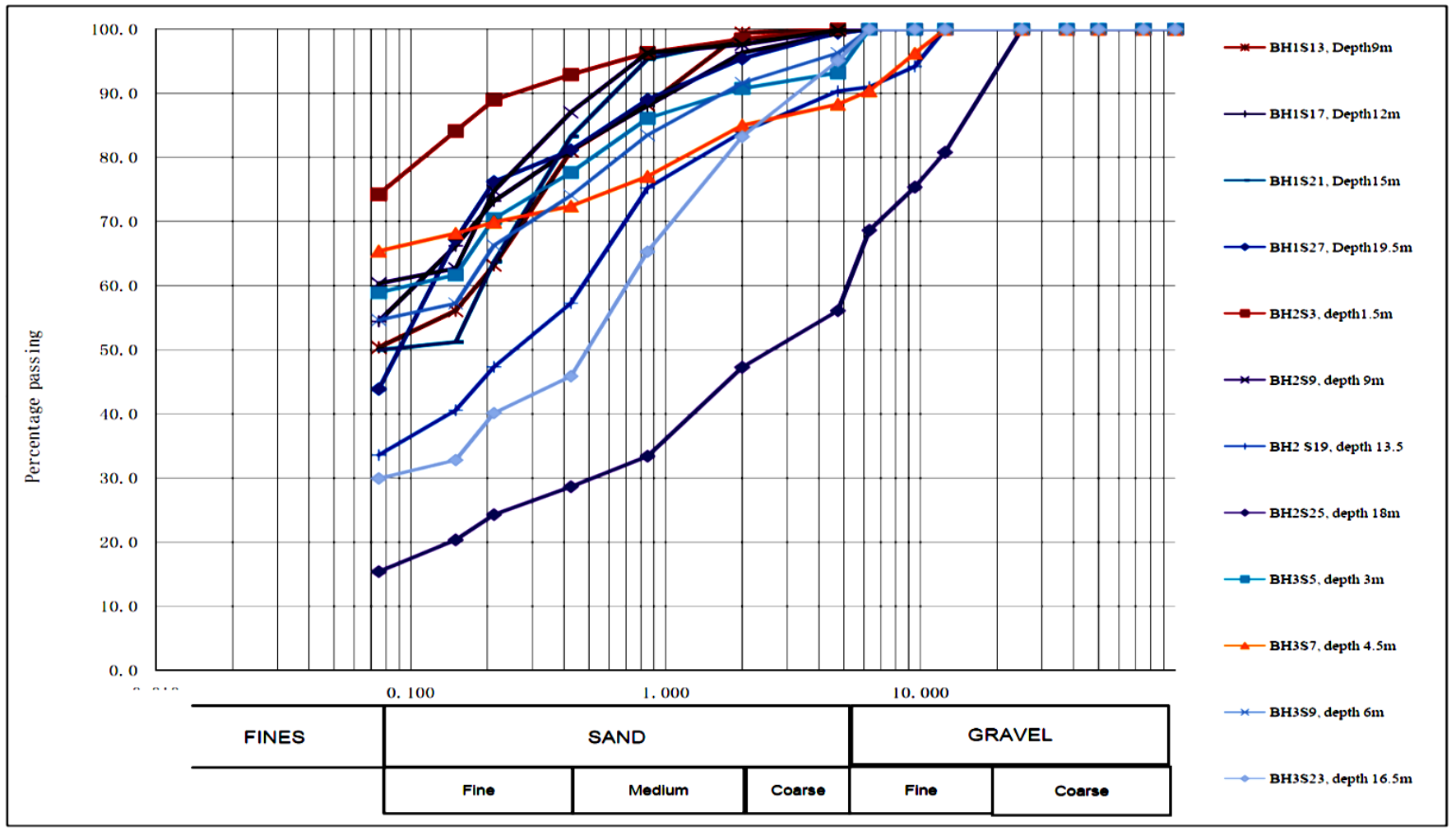

Figure 3: Particle Size Distribution of some Selected Soil Samples

\subsection{Atterberg's Limits and Other Physical Properties}

The range of values from non-plastic to obtained values (in percentages) for the samples are specified as, liquid limits; 44 - 58, plastic limits; 18 - 26 and plasticity index; 30 - 34 which indicate medium plastic to highly plastic material, [17] and [19]. In [19] it was recommend that, liquid limit not greater than $80 \%$ for sub-grade and not greater than $35 \%$ for sub-base and base course. Also, plasticity index not greater than $55 \%$ for sub-grade and not greater than $12 \%$ for both sub-base and base. From the examined soil samples, the soil fall within this specification, thus making them suitable for sub-grade, sub-base and base materials. The natural moisture content for all soil samples ranges between 13 and 20\%. Specific gravity ranges from 2.70 to 2.88 . Results of permeability test indicate low permeabilities of the soils in the range of $1.12^{*} 10^{-4} \mathrm{cms}^{-1}$ to $2.06^{*} 10^{-4} \mathrm{cms}^{-1}$, this is assumed to be due to the high fines present in the studied soil samples. The rate of consolidation through these soils consequently will be low since the soil permeability is a major factor in consolidation process. Table 2 shows physical properties of soil samples.

\subsection{Compaction Test}

Compaction tests carried out on samples using the standard proctor method indicate maximum dry densities of $2.05 \mathrm{Mgm}^{-3}, 1.78 \mathrm{Mgm}^{-3}$, and $1.69 \mathrm{Mgm}^{-3}$ for soil samples obtained from $\mathrm{BH} 1, \mathrm{BH} 2$ and $\mathrm{BH} 3$ respectively. Similarly, corresponding optimum moisture contents are $14.3 \%, 20.7 \%$ and $19.6 \%$ respectively. Plots of the dry densities against moisture contents are shown in Figure 4. Lines of optimum and zero air voids can be estimated for these set of curves. In [19], it was specified that, sub-base CBR values must not be less than $30 \%$ after 24-hour soaking when samples are compacted to $100 \%$ of maximum dry density at optimum moisture contents.

\subsection{Consolidation Test}

Compression indices $\left(\mathrm{C}_{\mathrm{c}}\right)$ obtained are $0.04816,0.03820$ and 0.04318 for tests on BH1, BH2 and BH3 samples 
respectively. Similarly, estimated expansion indices $\left(\mathrm{C}_{\mathrm{e}}\right)$ are $2.21^{*} 10^{-3}, 2.21^{*} 10^{-3}$ and $2.49^{*} 10^{-3}$ for tested samples at $\mathrm{BH} 1, \mathrm{BH} 2$ and $\mathrm{BH} 3$ respectively. The calculated coefficient of volume of compressibilities $\left(\mathrm{m}_{\mathrm{v}}\right)$, defined as the volume change per unit volume per unit increase in effective stress, [1] are $1.308^{*} 10^{-4}, 1.065^{*} 10^{-4}$ and $1.093^{*} 10^{-4} \mathrm{~m}^{2} \mathrm{kN}^{-1}$ respectively for samples in $\mathrm{BH} 1, \mathrm{BH} 2$ and $\mathrm{BH} 3$ respectively.

The e- $\log P$ plots are shown in Figure 5 and 6 . The moderate compressibility values make these soil samples suitable for construction purposes.

\subsection{California Bearing Ratio (CBR)}

Assessment of CBR value of 2.50 in unsoaked conditions of the compacted samples indicated 92.40, 78.40 and $42.10 \%$ for $\mathrm{BH} 1, \mathrm{BH} 2$ and $\mathrm{BH} 3$ respectively while $\mathrm{CBR}$ value of 5.0 indicated $89.10,82.40$ and $52.70 \%$

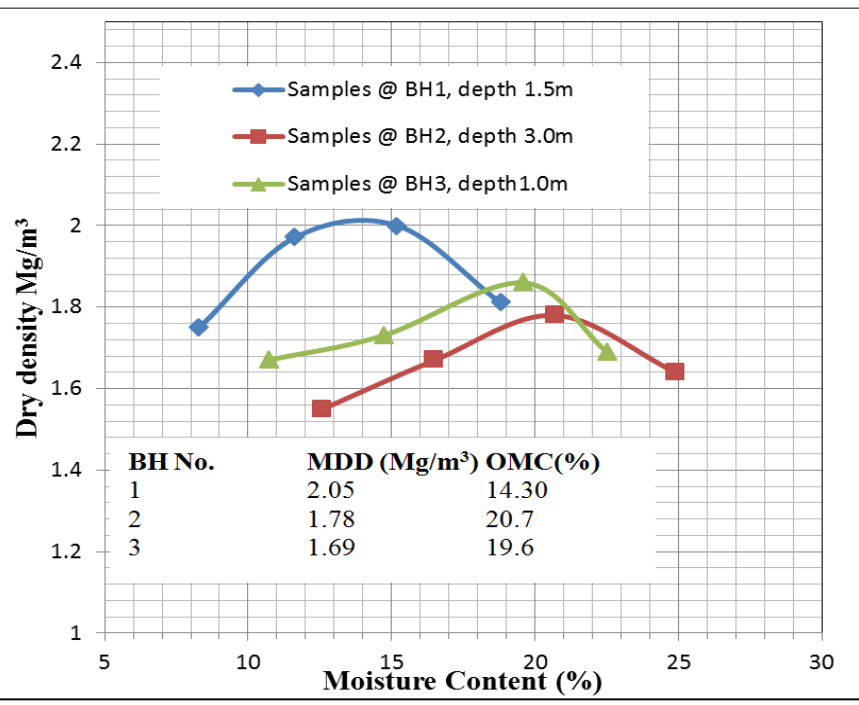

Figure 4: Dry Density $\left(\mathrm{Mgm}^{-3}\right)$ against Moisture Content (\%)

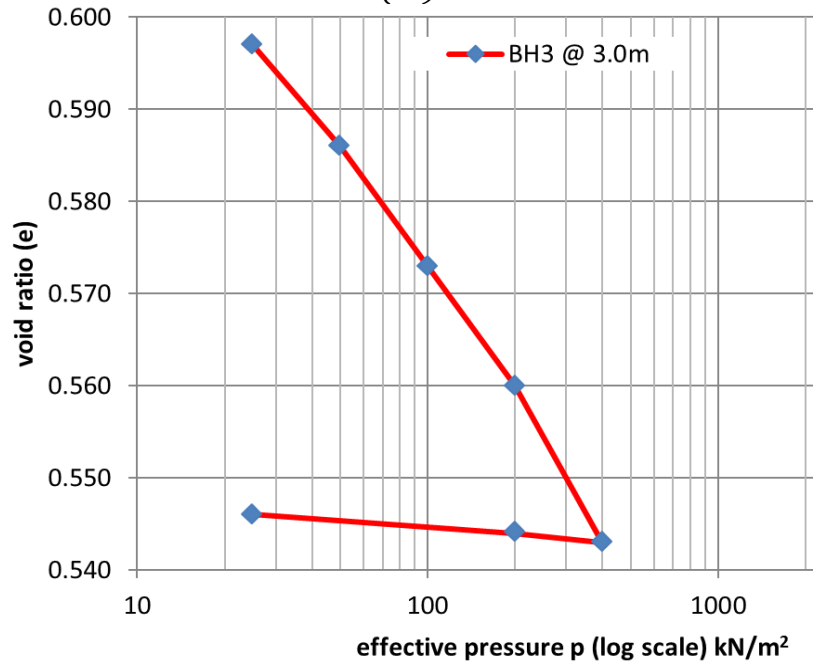

Figure 6:e-logP Plot for Soil Sample at BH 3 respectively. These values indicate that the soil is suitable for subgrade, sub-base and base course materials in road works because they all fall within the permissible range in the relevant codes that is, $[18-20]$. Plots of force $(\mathrm{kN})$ against corresponding penetration $(\mathrm{mm})$ are show in Figure 7. The soil profile and stratigraphic sequence is shown in Figure 8. From the soil probe, overall depth of the soil profile is approximately $19.5 \mathrm{~m}$, after which rock was encountered in the three borings. Further exploration activities could only be achieved with rock coring which is out of scope of this work. More details on soil geotechnical properties at the study area can be obtained from [8], for instance, the undrained cohesion ranges from $128 \mathrm{kN} / \mathrm{m}^{2}$ to $154 \mathrm{kN} / \mathrm{m}^{2}$ while the undrained angle of internal friction ranges from $15^{\circ}$ to $20^{\circ}$, [8].

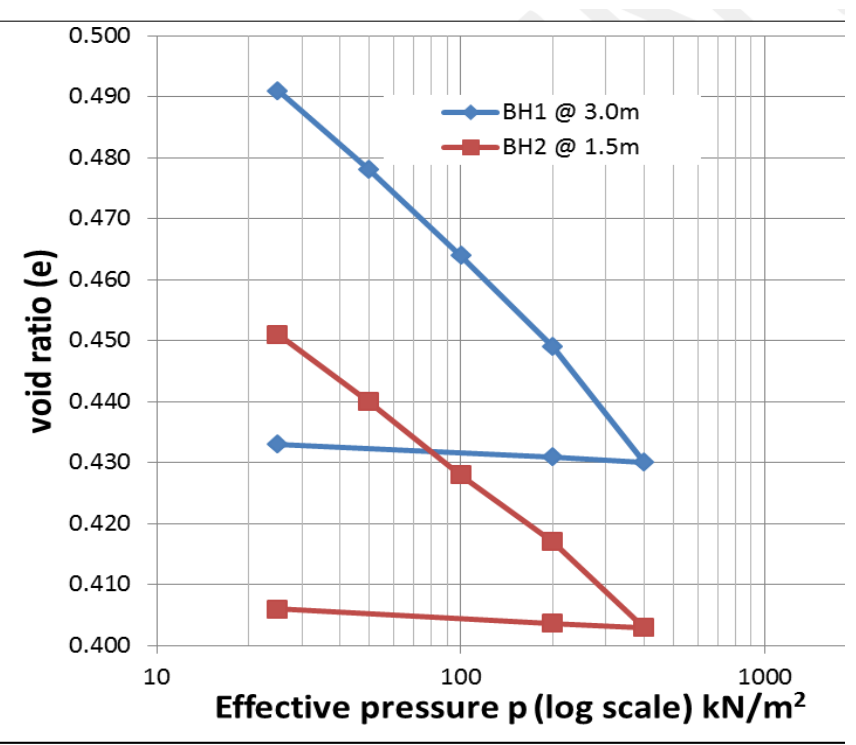

Figure 5: e-logP Plots for Soil Samples at BH 1 and BH2.

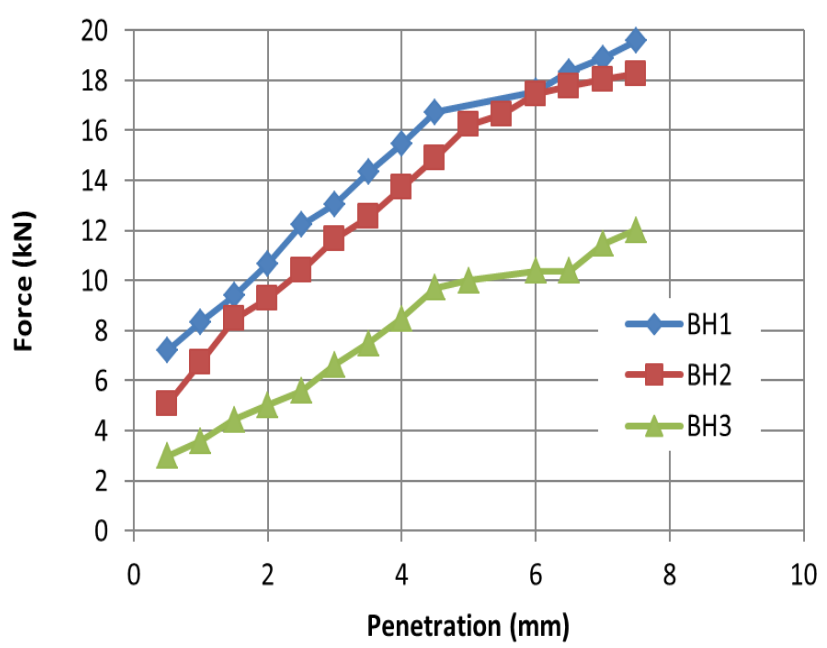

Figure 7: Relationship between Force and Penetration for Samples BH1, BH2 and BH3 


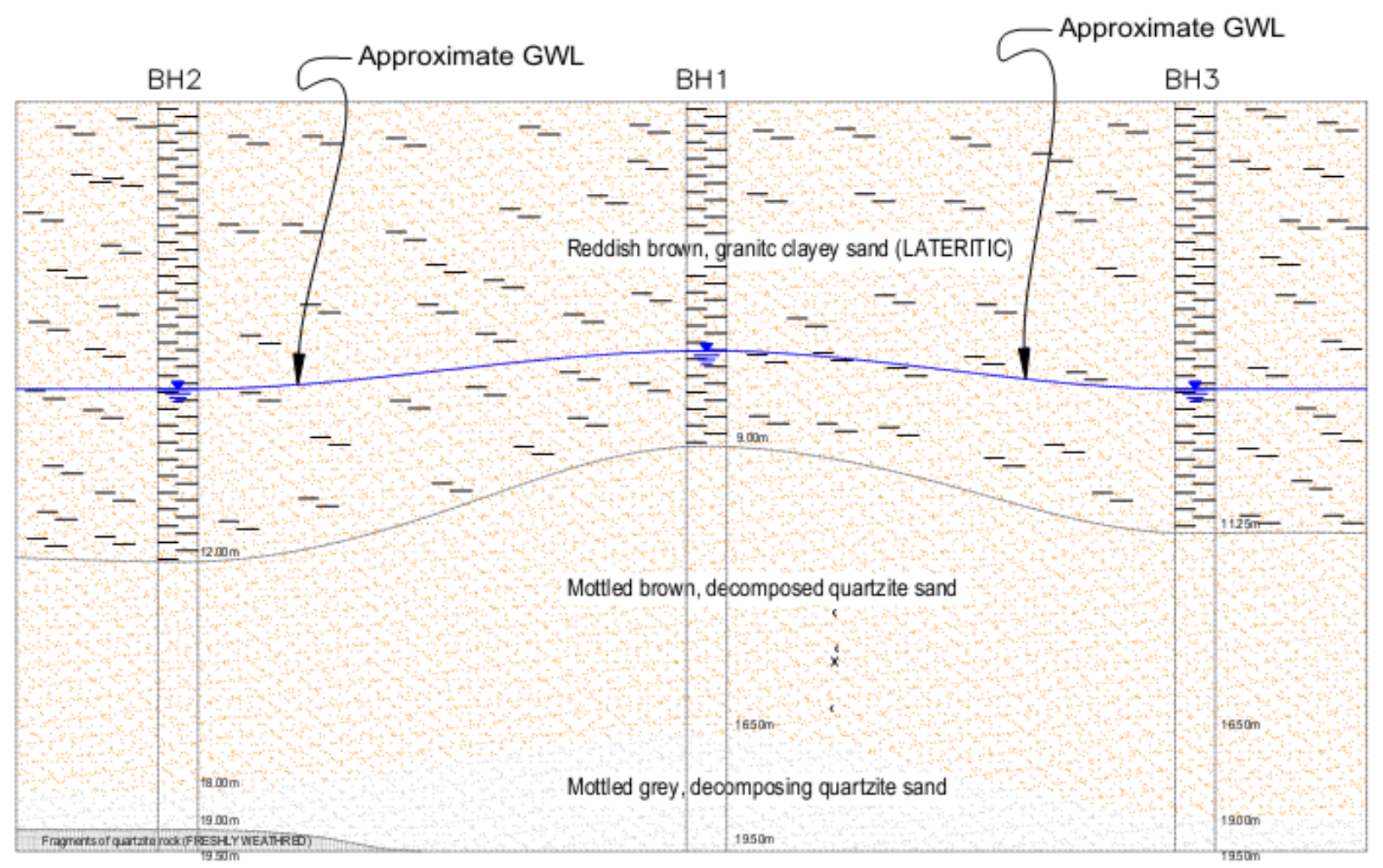

Figure 8: Soil Profile indicating Groundwater Level in the Study Area

\section{CONCLUSIONS}

From the soil exploration and laboratory analysis, it is inferred that, the soils encountered from the superficial to about $12 \mathrm{~m}$ depth are mostly lateritic soils because they possess both cohesive and cohesionless soil properties. Maximum compaction of soil samples can be achieved at the obtained MDD and respective OMC's. The groundwater level ranges from $6.5 \mathrm{~m}$ to $7.5 \mathrm{~m}$, $\mathrm{pH}$ values indicate that, ground water obtainable from the study area can be used for construction purposes, as the chloride and sulphate contents are within the permissible values obtainable from [18] and [20]. Differential Settlements or other forms of settlement are not anticipated if imposed structural loads are not more than $200 \mathrm{kN} / \mathrm{m}^{2}$. It is recommended that, future research on the soil samples of the study area should include Diffrential Thermal Analysis (DTA), Electron Microscopy and other mineral analysis to ascertain the clay minerals present in soils. Apart from the soil's suitability as a subgrade, subbase and base course materials in highway construction, they can be recommended for making mud blocks which is useful in building works since cement blocks are very expensive nowadays. Consequent upon the above summary, it is clear that objectives of this work have been met.

\section{ACKNOWLEDGEMENT}

This research work was sponsored by the "Tertiary Education Fund" (TETFUND), Nigeria. We therefore humbly acknowledge the force behind this work.

\section{REFERENCES}

[1] Craig, R. F. Craig's Soil Mechanics, Spon Press. Seventh Edition, 2004.

[2] Ademilua, O. L. "A Geoelectric and Geologic Evaluation of Groundwater Potential of Ekiti and Ondo States, Southwestern Nigeria", Unpublished M.Sc. Thesis, Department of Geology, Obafemi Awolowo University, Ile Ife, Nigeria. Pp. 1-67, 1997.

[3] Adetoro, A. E. and Ayeni, I. S. "Effects of Locally Available Additives on Geotechnical Properties of Ijero Local Government Soil, Ekiti State, Nigeria", Journal of Multidisciplinary Engineering Sciences and Technology (JMEST), Vol. 2, Isssue 11, Pp 2994-2997. 2015a.

[4] Adetoro, A. E. and Faluyi, O. S. "Potentials of NonCementitious Additives for Stabilization of Oye Local Government Area Soils, Ekiti State, Nigeria", International Journal of Scientific Research in Knowledge, Vol. 3, No. 11, , Pp 288-296. 2015b.

[5] Agbede, I. O. and Joel, M. "Effect of Rice Husk on the Properties of Ibaji Burnt Clay Bricks", American 
Journal of Scientific and Industrial Research, Pp674-677. 2011.

[6] Amadi, A. "Evaluation of Changes in Index Properties of Lateritic Soil Stabilized with Fly Ash", Leonardo Electronic Journal of Practices and Technologies, Issue 17, 2013, Pp 69-78, Available: http://lejpt.academicdirect.org, 2013.

[7] Amu, O. O., Oguniyi, S. A. and Oladeji, O. O. "Geotechnical Properties of Lateritic Soil Stabilized with Sugarcane Straw", American Journal of Scientific and Industrial Research, Vol. 2, Issue 2, 2011a, Pp 323-339. 2011.

[8] Adeyeri, J. B., Bolarinwa, A. and Okeke, T. C. "Geotechnical Properties of Soils in Ikole - Ekiti Area, Southwestern Nigeria", Electronic Journal Geotechnical Engineering, Vol. 22, No.1, Pp 21-32. Available at ejge.com, 06/02/2017, 12.00pm. 2017.

[9] Okunade, E. A. "Design and Implementation of a Web-Based Geotechnical Database Management System for Nigerian Soils", Modern Applied Science, Vol. 4, No. 11, Pp 36-42, 2010.

[10] www.ekitistate.gov.ng, 12/12/, 12.00pm. 2016.

[11] Ayodele, 0. S. "Geology and Structure of the Precambrian Rocks in Iworoko, Are, and Afao Area, Southwestern, Nigeria", International Research Journal of Natural Sciences, Vol. 1, No. 1, Pp 14 29. 2013.

[12] Ajibade, A. C. and Umeji, A. C. "Precambrian Geology if Nigeria" Geological Survey of Nigeria 1989, Pp 11-41

[13] Bayowa, O. G., Olorunfemi, O. M., Akinluyi, O.F., and Ademilua, 0. L. "A Preliminary Approach to Groundwater Potential Appraisal of Ekiti State, Southwestern Nigeria", International Journal of Science and Technology (IJST), Vol. 4, No. 3, Pp 4858. 2014,
[14] Okwoli, E., Onoja, O. S., and Udoeyop, U. E. “Ground Magnetic and Electrical Resistivity Mapping for Basement Structures Over Charnokitic Terrain in Ado Ekiti Area, Southwestern Nigeria", International Journal of Science and Technology (IJST), Vol. 3, No. 10, , Pp, 683-689. 2014.

[15] Oyinloye, A. O. "Geology and Geotectonic Setting of the Basement Complex Rocks in Southwestern Nigeria: Implications on Provenance and Evolution", Earth and Environmental Sciences, 2011, $\quad$ Pp 98 117.http://www.intechopen.com/books/earthand -environmental-sciences/geology-andgeotectonic-setting-of-the-basement-complexrocks-in-southwestern-nigeriaimplications8/05/2016 at $1.30 \mathrm{pm}$

[16] Talabi, A. O., Ademilua, O. L., Ajayi, O. Z. and Oguniyi, S. O. "Preliminary Geophysical Evaluation of Orin Bauxite Deposit, Southwestern Nigeria", Journal of Emerging Trends in Engineering and Applied Sciences(JETEAS), Vol. 4, No. 3, 2013, Pp 432-437

[17] Oladapo, M. I. and Ayeni, O. G. "Hydrogeophysical Investigation in Selected Parts of Irepodun/Ifelodun Local Government Area of Ekiti State, Southwestern Nigeria", Journal of Geology and Mining Research, Vol. 5, No.7, 2013, Pp 200 207

[18] British Standards 1377. Methods of Tests for Soils for Civil Engineering, 1990

[19] Federal Ministry of Works and Housing. General Specifications for Roads and Bridges, Volume II, 1994, pp 145-284

[20] ASHTO. Standard Specifications for Transportation Materials and Methods of Sampling and Testing, Washington, DC, 14th Ed. 1986. 